\title{
Low temperature caused modifications in the arrangement of cell wall pectins due to changes of osmotic potential of cells of maize leaves (Zea mays L.)
}

\author{
Anna Bilska-Kos ${ }^{1,5} \cdot$ Danuta Solecka $^{2} \cdot$ Aleksandra Dziewulska $^{2,6} \cdot$ Piotr Ochodzki $^{3}$. \\ Maciej Jończyk ${ }^{2} \cdot$ Henryk Bilski ${ }^{4} \cdot$ Pawel Sowiński $^{2}$
}

Received: 24 August 2015 / Accepted: 6 May 2016/Published online: 19 May 2016

(C) The Author(s) 2016. This article is published with open access at Springerlink.com

\begin{abstract}
The cell wall emerged as one of the important structures in plant stress responses. To investigate the effect of cold on the cell wall properties, the content and localization of pectins and pectin methylesterase (PME) activity, were studied in two maize inbred lines characterized by different sensitivity to cold. Low temperature $\left(14 / 12^{\circ} \mathrm{C}\right)$ caused a reduction of pectin content and PME activity in leaves of chillingsensitive maize line, especially after prolonged treatment ( $28 \mathrm{~h}$ and 7 days). Furthermore, immunocytohistological studies, using JIM5 and JIM7 antibodies, revealed a decrease of labeling of both low- and high-methylesterified pectins in this maize line. The osmotic potential, quantified by means of incipient plasmolysis was lower in several types of cells of
\end{abstract}

Handling Editor: David McCurdy

Anna Bilska-Kos

a.bilska@ihar.edu.pl

1 Department of Plant Biochemistry and Physiology, Plant Breeding and Acclimatization Institute - National Research Institute,

Radzików, 05-870 Błonie, Poland

2 Department of Plant Molecular Ecophysiology, Faculty of Biology, Institute of Plant Experimental Biology and Biotechnology, University of Warsaw, Miecznikowa 1, 02-096 Warsaw, Poland

3 Department of Plant Pathology, Plant Breeding and Acclimatization Institute - National Research Institute, Radzików, 05-870 Błonie, Poland

4 Laboratory of Electron Microscopy, Nencki Institute of Experimental Biology, PAS, Pasteura 3, 02-093 Warsaw, Poland

5 Present address: Department of Plant Physiology, Institute of Applied Biotechnology and Basic Science, University of Rzeszow, Werynia 502, 36-100 Kolbuszowa, Poland

6 Biomedical Sciences Research Complex North Haugh, University of St. Andrews, KY16 9ST, St. Andrews, Fife, Scotland, UK chilling-sensitive maize line which was correlated with the accumulation of sucrose. These studies present new finding on the effect of cold stress on the cell wall properties in conjunction with changes in the osmotic potential of maize leaf cells.

Keywords Cell wall $\cdot$ Cold stress $\cdot$ Osmotic potential · Pectins $\cdot$ Zea mays

$\begin{array}{ll}\text { Abbreviations } \\ \text { BS } & \text { bundle sheath } \\ \text { CC } & \text { companion cell } \\ \text { CS } & \text { chilling-sensitive maize line } \\ \text { CT } & \text { chilling-tolerant maize line } \\ \text { KMS } & \text { kranz mesophyll } \\ \text { PME } & \text { pectin methylesterase } \\ \text { PMEI } & \text { pectin methylesterase inhibitor } \\ \text { SE } & \text { thin-walled sieve tube } \\ \text { SET } & \text { thick-walled sieve tube } \\ \text { VP } & \text { vascular parenchyma }\end{array}$

\section{Introduction}

Cell walls, "the first line of protection", take a crucial part in the plant functioning, starting from determination of cell shape, due to its mechanical properties, to the protection against negative impact of environmental factors. Dynamic nature of the cell wall is maintained by modification of polysaccharides - its main structural component. In general, primary cell wall polysaccharides in the majority of terrestrial plants can be classified into three groups: cellulose, hemicelluloses, and pectins where cellulose is organized in microfibrils embedded in the matrix formed by pectins and 
hemicelluloses (Park and Cosgrove 2015). Pectins characterized by high galacturonic acid content, were classified into four main groups: homogalacturonan (HGA), rhamnogalacturonan I (RGI), rhamnogalacturonan II (RGII), and xylogalacturonan (XGA) (Ridley et al. 2001; Mohnen 2008). HGA polysaccharide, the major compounds of pectin, consists of galacturonosyl residues which may be methylesterified, acetylated and/or substituted with other subunits, including xylose (Schols et al. 1995; O'Neill and York 2003). Chemical modifications in HGA chains, especially the process of de-esterification (and subsequent calcium binding), which is under the control of pectin methylesterase (PME, EC. 3.1.1.11) have an influence on the biomechanical properties (e.g., plasticity, stiffness) of the cell wall (Parre and Geitmann 2005; Siedlecka et al. 2008; Yang et al. 2010; Hongo et al. 2012; Liu et al. 2013). Furthermore, the level of methyl esterification of pectins can indicate the stage of actual growth and development of cells (Willats et al. 2001). The structure and composition of cell wall can be modified by various abiotic stress factors. Changes may affect the biomechanical properties, e.g., through chemical modifications of the cell wall components. For instance, in coffee (Coffea arabica L.) leaves salt stress caused changes in pectic fractions, which led to the stiffening of the cell wall resulting in decreasing of its permeability for salt (Lima et al. 2014). Similarly, in petioles of an aspen hybrid (Populus tremula $\times$ tremuloides) increased rigidity of the cell wall formed a barrier for salt entrance (Muszyńska et al. 2014). Drought induced changes in the concentration of hemicellulose in switchgrass (Panicum virgatum L.) (Jiang et al. 2012). Next, phenomenon of desiccation tolerance of xerophyte plant (Myrothamnus flabellifolius) is connected with arabinan-rich leaf cell walls (Moore et al. 2006). Whereas, the acclimation of maize (Zea mays) root to drought is associated with the increase of walllinked phenolics in the tip and lignins in the stele (Fan et al. 2006). Deficit in the mineral nutrition led to reduction of cellulose content and a lower degree of pectin methyl esterification in grapevine (Vitis vinifera L.) callus (Fernandes et al. 2013). Aluminum stress caused an increase in the content of pectin in roots of maize and wheat, while in cell wall of flax hypocotyl (Linum usitatissimum L.) treated with cadmium content of high-esterified homogalacturonans were reduced (Eticha et al. 2005; Hossain et al. 2006; Douchiche et al. 2010). Overexpression of enzyme responsible for pectin degradation (the $\beta$ subunit of polygalacturonase 1) led to increased sensitivity of transgenic rice plants to cold, drought, and salt stresses (Liu et al. 2014). High temperature $\left(37^{\circ} \mathrm{C}\right.$ ) induced arabinose and galactose overaccumulation and reduced the mannose, glucose, uronic acid, rhamnose, and fucose contents in coffee leaves (Lima et al. 2013). Solecka et al. (2008) demonstrated that in cold-acclimated leaves of winter oil-seed rape changes in the pectins content and PME activity have been associated with modifications of the biomechanical properties (higher rigidity) of cell wall. Cold acclimation also resulted in increase in the content of other cell wall sugars, such as galactose, arabinose, and glucose in these plants (Kubacka-Zębalska and Kacperska 1999). In response to cold acclimation of $\mathrm{C}_{4}$ grass from genus Miscanthus, a significant increase in phenylalanine ammonia-lyase (PAL) activity and decrease in lignin content in cell walls were observed (Domon et al. 2013).

Specific regions of cell wall, called "pit fields", are traversed by plasmodesmata, minute channels by which the intercellular transport occurs in plants. These structures are particularly important for $\mathrm{C}_{4}$ plants where the photosynthesis process is distributed spatially. In more detailed view: in the mesophyll cells primary carbon assimilation (PCA) occurs while associated process of the photosynthetic carbon reduction (PCR) is carried out in the bundle sheath cells (Hattersley 1984). This spatial distribution of photosynthesis requires an efficient intercellular transport and thus, the sufficient permeability of plasmodesmata. It is also possible that the capacity of plasmodesmata may depend on the properties of surrounding cell walls.

This work was aimed on verifying the hypothesis that the decrease in osmotic potential of cells of maize leaves at cold through the sucrose accumulation may be associated with changes in cell wall properties, specified by pectin reorganization. This hypothesis has been emerged from our earlier work on changes of transcriptome in leaves of maize, where numerous genes related to cell wall functioning responded to cold stress (Trzcinska-Danielewicz et al. 2009; Sobkowiak et al. 2014). It may suggest that chilling treatment modifies the cell wall properties. Additionally, our previous studies indicated that low temperature inhibited intercellular transport in leaves of chilling-sensitive maize line what was related to the closure of plasmodesmata on the photosynthetic pathway (Bilska and Sowiński 2010). Thus, in this work particular attention has been paid to regions of cell wall with plasmodesmata (pit fields). Modifications of plasmodesmata ultrastructure could lead to increase of sucrose content in photosynthetically active cells and changes in their osmotic potential what could be stimulus for changes of the cell wall properties.

\section{Materials and methods}

\section{Plant material, growth condition and chilling-treatment periods}

For studies chilling-tolerant (CT) KW 1074 (Zea mays spp. indurata, flint) and chilling-sensitive (CS) CM 109 (Z. mays spp. indentata, dent) maize lines were used. Differences in the chilling sensitivity of the inbred lines used have been described elsewhere (Sowiński 1995). Kernels were germinated 
in wet sand in darkness at $25^{\circ} \mathrm{C}$. Then, plants were transferred to hydroponic media (Knop solution supplemented with Hoagland's micronutrients). Seedlings were grown in a growth chamber with parameters set to: $14 / 10 \mathrm{~h}$ light/darkness, irradiance $250 \mu \mathrm{mol}$ quanta $\mathrm{m}^{-2} \mathrm{~s}^{-1}$ at $24 / 22{ }^{\circ} \mathrm{C}$ (day/ night temperature). When the third leaf was fully developed, at the beginning of the light period, plants were transferred to low temperature $14 / 12{ }^{\circ} \mathrm{C}$ (day/night) for either $1,4,28$, or $168 \mathrm{~h}$ ( 7 days). Chilling treatment was started at the beginning of the light period and control samples were taken $4 \mathrm{~h}$ after the light had been switched on, except the analysis of the sucrose content, where additional control (variants: c0, c1, c4, c8, c12, c28) and chilled (1, 4, 8, 12, and 28 h) plants were used. Each analysis was repeated three times in four independent experiments.

\section{Cell wall preparation and pectin content determination}

The analysis of pectin content, PME activity and pectin immunolocalization was performed for control plants and those chilled for 4 h, 28 h, and 7 days. Cell walls from maize leaf laminas were prepared using a modified method of $\mathrm{Wu}$ et al. (1996). Fresh leaf tissues were homogenized at $4{ }^{\circ} \mathrm{C}$ in HEPES buffer (0.05 M, pH 6.8), containing a mixture of protease inhibitors (PMSF, aprotinin, bestatin, pepstatin A, and leupeptin), filtered through a miracloth and washed several times with cold water. After air drying, crude cell wall preparations from maize leaves were weighted and used for determination of pectin content. Cell wall content was expressed in milligrams per $1 \mathrm{~g}$ of leaf dry weight (DW).

Pectin isolation was performed as described by KubackaZębalska and Kacperska (1999). In brief: crude cell wall preparations were subjected to $90 \%$ DMSO treatment to remove starch.

The Lugol's test was used to confirm that the material is free of starch (data not shown).

Air-dried cell wall aliquots ( $1 \mathrm{~g})$ were extracted with a mixture of CDTA and Na-acetate $(50 \mathrm{mM}, \mathrm{pH} 6.5)$, for $6 \mathrm{~h}$ and then with CDTA $(50 \mathrm{mM})$ for $2 \mathrm{~h}$ at room temperature. The combined extracts were centrifuged (12,000 g, $15 \mathrm{~min}$ ) and concentrated by evaporation under vacuum. The concentrate was dialyzed for $72 \mathrm{~h}$ against deionized water and dried under vacuum. Pectin content was expressed in milligrams per 1 gram of cell wall preparations. Differences between the experimental variants were evaluated by Tukey test at 0.05 and 0.01 probability levels, using STATISTICA 7.0 PL software (Statsoft, USA).

\section{Determination of PME activity}

Determination of the enzymatic activity was performed according to Solecka et al. (2008). Cell wall proteins were extracted from crude cell wall preparations with HEPES buffer
(0.05 M, pH 6.8), containing $1 \mathrm{M} \mathrm{NaCl}$ and a mixture of protease inhibitors (PMSF, aprotinin, bestatin, pepstatin A, and leupeptin). Protein concentration in extracts was determined by the Bradford method (1976), using bovine serum albumin (Sigma, Germany) as a standard. Protein extracts from cell walls were used for determination of PME activity.

Reaction mixtures contained $0.5 \%(w / v)$ highlymethylated citrus pectins (Sigma, Germany), 0.2 $\mathrm{M} \mathrm{NaCl}$ and $0.015(w / v)$ Methyl Red (Sigma, Germany) as a $\mathrm{pH}$ indicator. Changes in color from yellow to red (due to $\mathrm{pH}$ lowering during pectin de-esterification) were measured spectrophotometrically at $525 \mathrm{~nm}$ (Shimadzu, Japan) for $3 \mathrm{~min}$ at $25^{\circ} \mathrm{C}$. A calibration curve was obtained by adding 1 to $200 \mathrm{nEq} \mathrm{H}+$ to $1 \mathrm{ml}$ of reaction mixture and the enzyme activity was calculated on the basis of cell wall proteins. The enzymatic activity was expressed in PME units. One unit was defined as one nanoequivalent of protons $\left(\mathrm{nEH}^{+}\right)$released by one milligram of cell wall proteins during $1 \mathrm{~min}$, and was also recalculated per gram of cell wall matter. Differences between the experimental variants were evaluated by Tukey test at 0.05 and 0.01 probability levels, using STATISTICA 7.0 PL software (Statsoft, USA).

In preliminary experiments, the PME activity was measured at three different $\mathrm{pH}$ values: 5.0, 6.8, and 8.5. PME activities determined at acidic or alkaline $\mathrm{pH}$ were low and were not significantly affected by the cold-acclimation conditions (data not shown). Therefore, only the enzymatic activities determined at neutral $\mathrm{pH}$ are reported in the present paper.

\section{Immunolocalization of pectins}

For these studies samples were fixed in $4 \%$ paraformaldehyde (PFA) in 0.1 M phosphate buffer, $\mathrm{pH} 7.3$ at room temperature. After dehydration (ethanol 10-100\%) the material was embedded in LR White resin (London Resin Company, UK) and polymerized for $24 \mathrm{~h}$ at $37^{\circ} \mathrm{C}$. Ultrathin $(80 \mathrm{~nm})$ sections were cut with a diamond knife on a Leica Ultracut UTC ultramicrotome. Immunolocalization of pectins were performed using monoclonal antibodies (Plant Probes, UK) against lowesterified pectins (rat IgG, JIM5) and against highly esterified pectins (rat IgA, JIM7) (Knox et al. 1990; Clausen et al. 2003). In the first stage of immunolabeling, the blocking of unspecific epitopes was performed using powdered milk solution $(0.3 \%, w / v)$ with Tween $(0.1 \%)$ in PBS (0.1 M, pH 7.3). After series of washing cycles (in PBS, 0.1 M, pH 7.3), samples were incubated for $1.5 \mathrm{~h}$ at room temperature with primary antibodies (JIM5 and JIM7) — both diluted 1:100. In case of negative control this step was omitted. Next, the material was washed (PBS, 0.1 M, pH 7.3) and incubated for $1 \mathrm{~h}$ at room temperature with secondary antibodies conjugated to $10 \mathrm{~nm}$ gold particles (goat anti-rat, SIGMA) in 1:30 dilution. Samples were finally contrasted with uranyl acetate for $20 \mathrm{~min}(5 \%)$ and lead citrate for $30 \mathrm{~min}(0.04 \%)$. Electron 
microscope observations were done using transmission electron microscope (model JEM 1200 EX; JEOL Co., Japan).

\section{Quantitative analysis of labeling density}

The quantitative analysis of labeling density was performed following the method described by Morvan et al. (1998) using iTEM software (Olympus, Germany). Gold particles were counted from cell wall section (at least 30 sections per experimental variant) at each analyzed interface. The values of labeling density are reported as the mean numbers of gold particles per $1 \mu^{2}$. For the analysis, six different cellular interfaces were chosen (Table 1). Gold particles from the cell wall forming intercellular spaces were not taken for counting. The differences, as calculated by comparing the number of gold particles between control (unchilled) and chilled leaves for each cellular interface were analyzed using the KruskalWallis test with Bonferroni correction procedure (SAS 9.1.3; SAS Institute, Cary, NC).

\section{Sucrose content}

The analysis of sucrose content was performed for control plants-variants: $\mathrm{c} 0, \mathrm{c} 1, \mathrm{c} 4, \mathrm{c} 8, \mathrm{c} 12$, and $\mathrm{c} 28$-and plants chilled for $1,4,8,12$, and 28 h using gas chromatography according to method described by Knudsen and Li (1991). Briefly, the fragment of leaf (about $200 \mathrm{mg}$ ) was crushed in liquid nitrogen. Next, the samples were homogenized using Ultra-Turrax 25 (IKA-Werke GmbH \& Co. KG, Germany) with the addition of the internal standard: phenyl- $\beta{ }^{-D^{-}}$ glucopyranoside (Sigma-Aldrich). After evaporation, the precipitate was dissolved by heating in hydroxylamine hydrochloride in pyridine $(25 \mathrm{mg} / \mathrm{ml})$. Next, derivatization was performed with hexamethyldisilazane (Sigma-Aldrich) and trifluoroacetic acid. Samples were analyzed using gas chromatograph HP 5890 Series IIA (Chemstation) equipped with a flame ionization detector (FID) and a quartz capillary column $(30 \mathrm{~m} \times 0.53 \mathrm{~mm})$. The chromatograph was connected to an autosampler HP 7363 (Hewlett-Packard) and controlled by Chemstation workstation.

\section{Plasmolysis}

Plasmolysis was determined for control plants and plants chilled for 1 and $4 \mathrm{~h}$ using a graded series of sorbitol solutions ranging from 0 to $1400 \mathrm{mM}$, in steps of $100 \mathrm{mM}$, as described elsewhere (Turgeon and Medville 1998). The method of the incipient plasmolysis allows studying directly the osmotic pressure of individual cells (osmoticum concentration of $1 \mathrm{M}$ equals to $2.78 \mathrm{MPa}$ of osmotic pressure, Turgeon and Medville 1998). For this approach, leaf samples were first pre-incubated for $20 \mathrm{~min}$ in an appropriate sorbitol solution (in $25 \mathrm{mM}$ PIPES-NaOH buffer) and then fixed overnight at
Table 1 Types of cellular interfaces selected for the quantitative analysis of labeling density

\begin{tabular}{ll}
\hline Cellular interface & Abbreviation \\
\hline Kranz mesophyll/bundle sheath & KMS/BS \\
Bundle sheath/vascular parenchyma & $\mathrm{BS} / \mathrm{VP}$ \\
Vascular parenchyma/companion cell & $\mathrm{VP} / \mathrm{CC}$ \\
Vascular parenchyma/thin-walled sieve & $\mathrm{VP} / \mathrm{SE}$ \\
Vascular parenchyma/thick-walled sieve & $\mathrm{VP} / \mathrm{SET}$ \\
Companion cell/thin-walled sieve & $\mathrm{CC} / \mathrm{SE}$ \\
\hline
\end{tabular}

For this analysis at least 30 cell wall sections (with an area of $1 \mu \mathrm{m}^{2}$ ) per experimental variant were taken

$4{ }^{\circ} \mathrm{C}$ in $2.5 \%$ glutaraldehyde supplemented with sorbitol at a concentration as during the pre-incubation. Next, samples were washed three times in PIPES-NaOH buffer and were post-fixed in $1 \%$ osmium tetroxide for $2 \mathrm{~h}$ at room temperature. After dehydration (ethanol 10-100\%) the material was embedded in the epoxy resin (Epon, Serva). It was assumed that the plasmolysis occurs when more than $30 \%$ of plasmalemma in the cell of a given type separated from the cell wall.

\section{Results}

\section{Changes in the cell wall and pectin content in leaves of maize due to chilling treatment}

In order to investigate the effects of chilling treatment on the cell wall properties of maize leaves the cell wall content as well as the pectin content and PME activity were determined. In this approach, the first step was the analysis of the cell wall content in leaf. The level of the cell wall fraction was similar in control plants of tested maize lines and was about 99 and 107 ( $\mathrm{mg} \mathrm{g}^{-1}$ dry weight), for chilling-tolerant (CT) and chillingsensitive (CS) lines, respectively (Fig. 1). Comparing to control in cold the content of cell wall fraction was higher in leaves of both maize lines. The effect was particularly significant in the CT line, where an increase of about $40 \%$ after prolonged chilling (7 days) was noted (Fig. 1). A marked decrease of pectin content was observed in chilled leaves of CS line after the week-long cold treatment (Fig. 2).

\section{The influence of low temperature on pectin methylesterase activity in leaves of maize}

In CT line, at first a slight increase in PME activity was observed followed by the decrease after prolonged chilling treatment: $28 \mathrm{~h}$ and 7 days (Fig. 3). In contrast, in leaves of CS line, PME activity significantly decreased just after $4 \mathrm{~h}$ of chilling treatment and was about $35 \%$ lower compared to leaves of control plants (Fig. 3). These changes intensified along with 


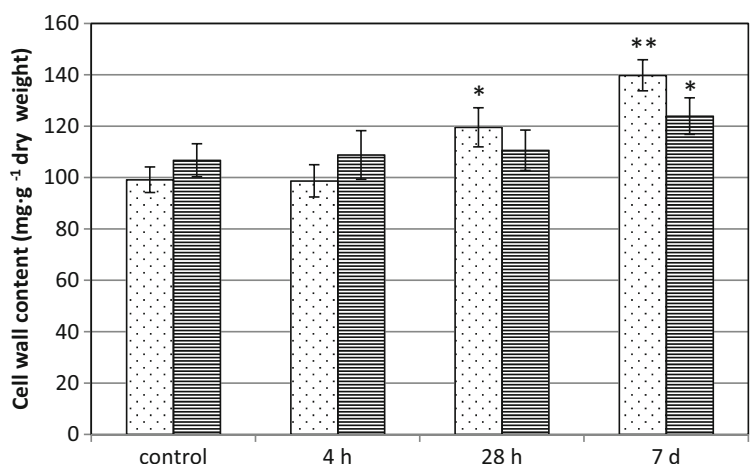

Fig. 1 Cell wall content in leaf cells of two maize inbred lines: chillingtolerant $(C T)$ and chilling-sensitive $(C S)$ treated with low temperature for three time periods: $4 \mathrm{~h}, 28 \mathrm{~h}$, and 7 days. Bars represent the mean $\pm \mathrm{SD}$ values. $* P<0.05, * * P<0.01$

lengthening of chilling-treatment period - up to about $55 \%$ in comparison to control. On the contrary, the decrease in PME activity in CT leaves observed after prolonged chilling treatment was only about $30 \%$ (Fig. 3).

\section{Pectin immunolocalization in cell wall-microscopic observations}

The observed cell system in the vascular vein, vein size, and distribution of veins in the leaf tissue were consistent with the typical leaf anatomy of $\mathrm{C}_{4}$ plants. The cell wall of bundle sheath cells was characterized by suberin layer which was observed in the middle lamella (Evert et al. 1996). Signal coming from both types of antibodies-JIM5 and JIM7, was detected in cell walls of all of the examined cellular interfaces (Fig. 4, and 5). Negative control where primary antibodies were omitted confirmed the reliability of the method - the labeling was not found within cell wall as well as in other cellular localization (Fig. 4a).

In most cell types of studied maize lines, pectins recognized by both types of antibodies were observed

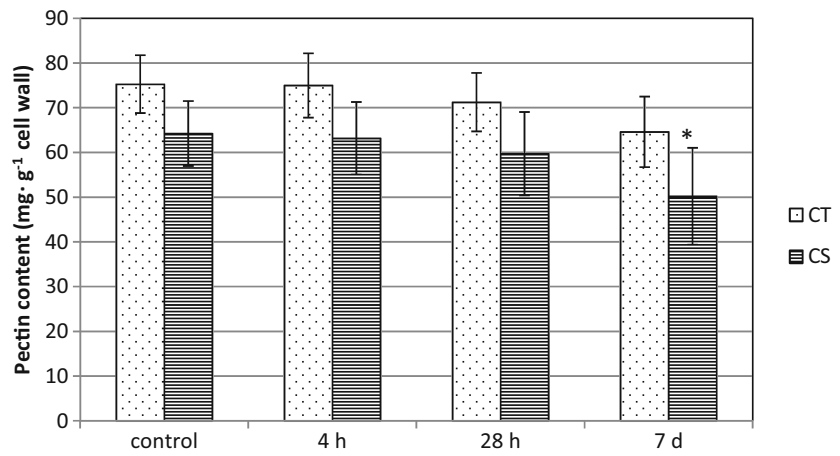

Fig. 2 Global pectin level in cell wall of leaf cells of two maize inbred lines: chilling-tolerant $(C T)$ and chilling-sensitive $(C S)$ treated with low temperature for three time periods: 4 h, 28 h, and 7 days. Bars represent the mean \pm SD values. $* P<0.05, * * P<0.01$

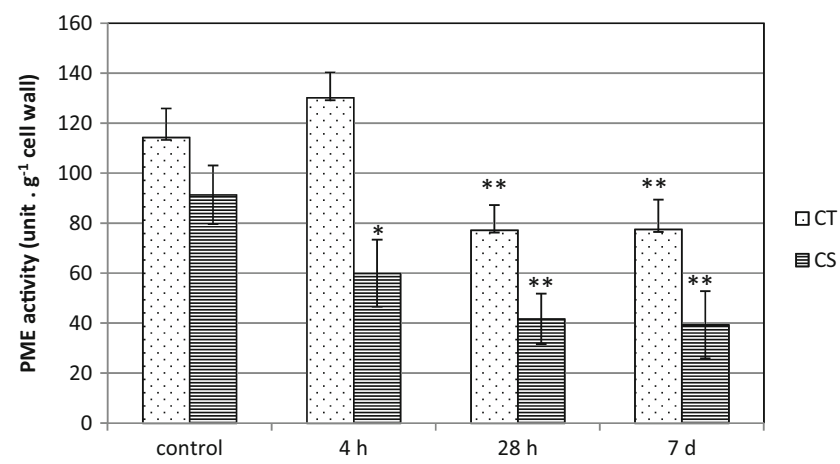

Fig. 3 Pectin methylesterase activity in leaf cells of two maize inbred lines: chilling-tolerant $(C T)$ and chilling-sensitive $(C S)$ treated with low temperature for three time periods: $4 \mathrm{~h}, 28 \mathrm{~h}$ and 7 days. Bars represent the mean \pm SD values. $* P<0.05, * * P<0.01$

predominantly in the primary cell wall close to the middle lamella (Fig. 4b-f, h Fig. 5c-f), as well as in the intercellular spaces (Fig. 4h, i, Fig. 5d, e, g, h). In case of all interfaces the distribution of gold particles was not dependent on the plasmodesmata presence (Fig. 4f, g, Fig. 5f, i). Chilling treatment did not cause significant changes in the intensity of labeling in the leaves of CT line. In contrast, plants of CS line showed in most cases reduction in the accumulation of gold particles for both used antibodies. Significance of these changes were confirmed by non-parametric, Kruskal-Wallis test (Table 2). A clear reduction in the number of gold particles for both antibodies was observed for most interfaces after prolonged cold treatment ( $28 \mathrm{~h}$ and 7 days) in leaves of CS line, especially for $\mathrm{KMS} / \mathrm{BS}, \mathrm{VP} / \mathrm{CC}, \mathrm{VP} / \mathrm{SET}$, and CC/SE interfaces (Fig. 5a, b, $\mathrm{d}-\mathrm{h}$, Table 2).

\section{Incipient plasmolysis in cells of maize leaves}

In cells of both maize lines without evidence for plasmolysis the continuity of protoplast adjacency to cell wall was observed. In control plants, KMS and BS cells plasmolysed in approximately the same concentration of sorbitol (Table 3). It was between 300 and $400 \mathrm{mM}$ for the $\mathrm{CT}$ and $400 \mathrm{mM}$ sorbitol for CS lines (Table 3; Fig. 6a, b). A strong difference in the osmoticum concentration that led to incipient plasmolysis was found for the CC/SE complex: these cells plasmolysed at a sorbitol concentration of $500 \mathrm{mM}$ in the $\mathrm{CC}$ cells and $800 \mathrm{mM}$ in the SE cells of CT line and at 300 or $200 \mathrm{mM}$ in the CS line (Table 3; Fig. 6c-f). Chilling of plants for 1 and $4 \mathrm{~h}$ did not distinctly change the osmotic potential of KMS, BS cells, and the CC/SE complex in the CT line (Table 3). The CS line responded to chilling (especially after $4 \mathrm{~h}$ ) by a strong increase of the concentration of osmoticum needed to cause incipient plasmolysis in KMS and BS cells, while the CC/SE 
Fig. 4 Immunogold localization of pectins using monoclonal antibodies: JIM5 specific to lowesterified pectins (b-e) and JIM7 specific to high-esterified pectins (f-i) in leaves of chilling-tolerant maize line. Negative control, where the incubation with primary antibodies was omitted (a). Control (non-chilled) leaves (b, d, f, h) and chilled leaves for $4 \mathrm{~h}(\mathrm{~g})$, $28 \mathrm{~h}(\mathbf{c}, \mathbf{e})$ and 7 days (i). Gold particles were mainly observed in the primary cell wall close to the middle lamella $(\mathbf{b}-\mathbf{f})$, with no relationship with the presence of plasmodesmata (f, g), and in the intercellular spaces (h, i). In chilled leaves, for $\mathrm{VP} / \mathrm{SE}$ and $\mathrm{CC} /$ SE interfaces decrease in the density of labeling was observed (h, i). KMS Kranz mesophyll; $B S$ bundle sheath; $V P$ vascular parenchyma; $C C$ companion cell; $S E$ thin-walled sieve tube; $S E T$ thick-walled sieve tube; $C W$ cell wall; $P d$ plasmodesmata; *intercellular space. Scale bar, $200 \mathrm{~nm}$
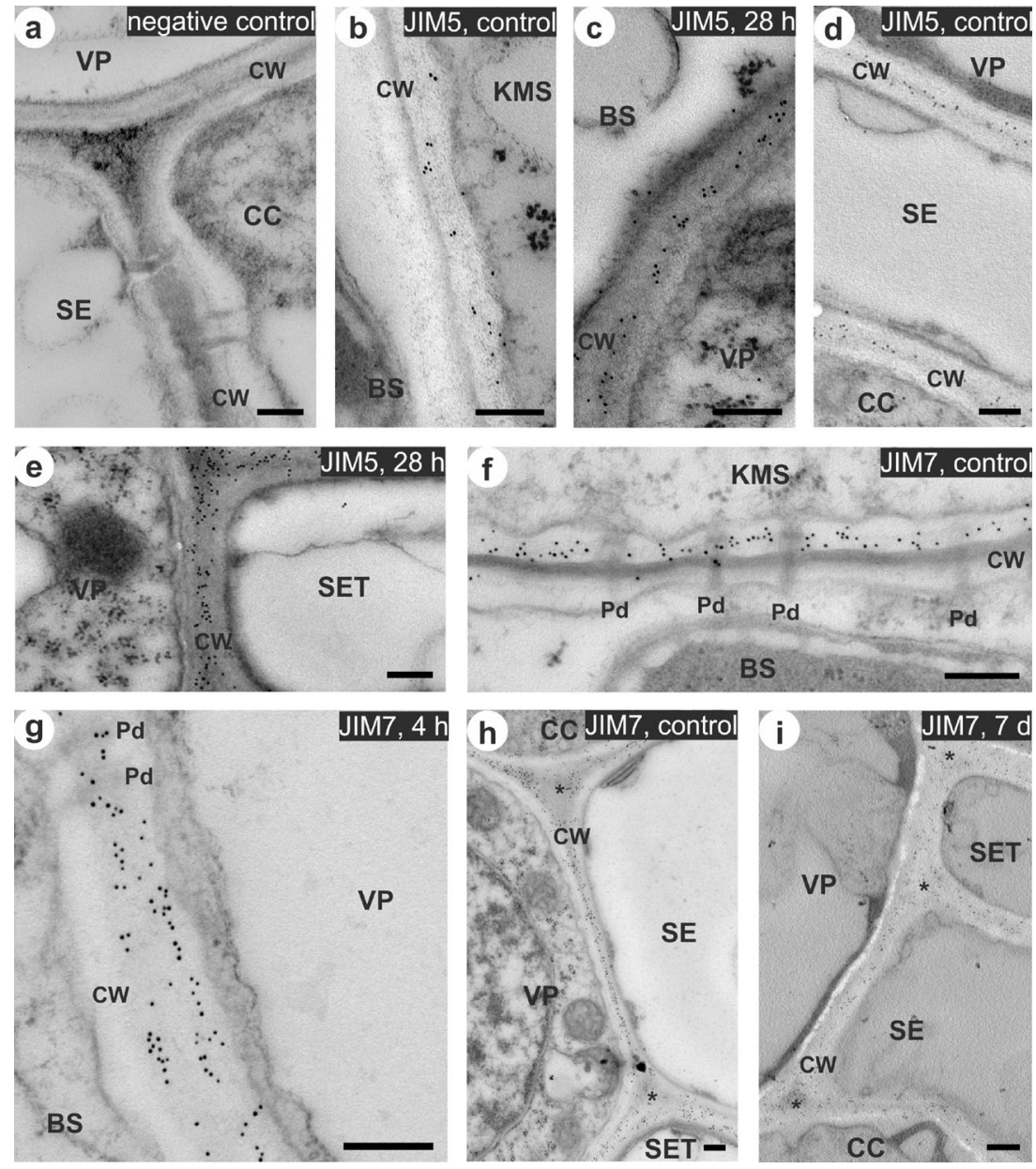

complex remained without significant changes in plasmolysis (Table 3; Fig. 6g, h).

\section{Changes in sucrose accumulation in chilled leaves of maize}

Sucrose content in the leaves of control plants of both maize lines corresponded to changes of sugar concentration occurring during the diurnal cycle - at the start of light exposure, the sucrose content was the lowest, and then it increased gradually until the end of exposure, and decreased at dark (Fig. 7). In the chilling-treated plants of $\mathrm{CT}$ line, the reduction of sucrose accumulation was observed, wherein, the trend of changes was similar to that obtained for the control plants. However, in CS line, after just the first hour of exposure to low temperature, a drastic increase of the sucrose content was found - the level of sugar was about three times higher compared to its content in leaves of control plants.

\section{Discussion}

In this paper, it was investigated whether changes in the osmotic potential of cells can lead to modification of cell wall properties via the deposition of pectins. The substantial and local changes in the osmoticum seem to be caused by overaccumulation of sucrose in the certain cells probably resulting from the occluded plasmodesmata.

\section{Are there any changes in cell wall properties under cold conditions?}

In this work the properties of the cell wall in the context of global pectin content and PME activity were examined in chilled leaves of two maize inbred lines. CS line was characterized by significantly lower PME activity at cold compared to control variant, what was depended on the duration of chilling treatment of plants (Fig. 3). At the same time, decrease in the content of pectins, particularly after 7 days of cold treatment was observed in leaves of CS line (Fig. 2). The impact of low temperature on the organization of components of the cell wall, including pectins, can be considered in two aspects, as a result of cold stress and as an effect of cold-acclimation process. In the 3-week cold-acclimated winter oilseed rape leaves, significant increase of pectin content was observed (Solecka et al. 2008). It was in accordance with high activity of PME enzyme and changes in biomechanical properties of 
Fig. 5 Immunogold localization of pectins using monoclonal antibodies: JIM5 specific to lowesterified pectins (a-e) and JIM7 specific to high-esterified pectins (f-i) in leaves of chilling-sensitive maize line. Control (non-chilled) leaves $(\mathbf{a}, \mathbf{d}, \mathbf{f})$ and chilled leaves for $4 \mathrm{~h}(\mathbf{c}, \mathbf{g}), 28 \mathrm{~h}(\mathbf{e}, \mathbf{i})$, and 7 days $(\mathbf{b}, \mathbf{h})$. Chilling caused reduction of number of gold particles, especially for: KMS/BS interface $(\mathbf{a}, \mathbf{b}, \mathbf{f}, \mathbf{i}), \mathrm{VP} / \mathrm{SET}$ and $\mathrm{CC} / \mathrm{SE}$ interfaces $(\mathbf{d}, \mathbf{e}, \mathbf{g}, \mathbf{h})$. $K M S$ Kranz mesophyll; $B S$ bundle sheath; $V P$ vascular parenchyma; $C C$ companion cell; $S E$ thin-walled sieve tube; $S E T$ thick-walled sieve tube; $C W$ cell wall; $P d$ plasmodesmata; $*$ intercellular space. Scale bar, $200 \mathrm{~nm}$
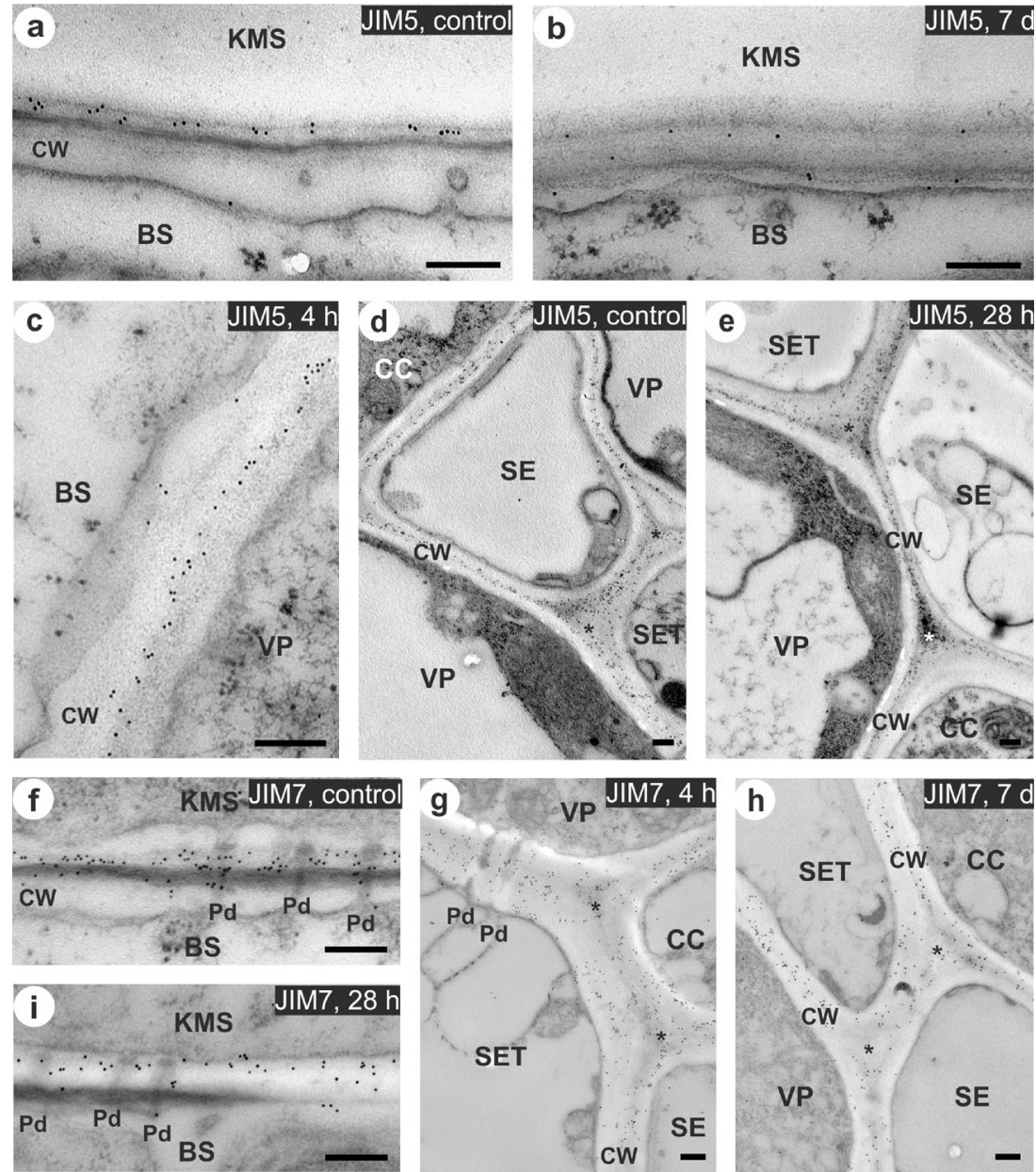

leaves, e.g., stiffened lamina. In this work the relatively short period of chilling treatment ( $4 \mathrm{~h}$ up to 1 week) of coldsensitive plants led to the reverse situation which may be the evidence of response of CS maize line to cold stress. This may reflect the necessity of changes in cell wall rigidity for maintaining turgor pressure in particular cells through changes in state of cell wall pectins (Haswell and Verslues 2015). Additionally, a significant reduction of labeling with JIM5 antibodies (which recognize low-esterified HGAs) was observed mainly in the intercellular connections between photosynthetically active cells: KMS and BS cells and CC/SE complex in leaves of CS maize line. The reduction in the level of low-esterified pectins caused by lower PME activity may indicate lower stiffness of the cell wall (Catoire et al. 1998). This loosened structure of the cell wall in CS leaves may be insufficient to maintain a proper turgor pressure, which is necessary in these types of cells and/or whole tissues. This observation also raises the question about the mode and the level of reguation of PME activity in stress conditions. The proteinaceous PME inhibitor (PMEI), ubiquitously expressed in higher plants, may provide an effective posttranslational control mechanism for PME activity
(Balestrieri et al. 1990; Jolie et al. 2010). PMEIs have revealed specificity toward plant PME only and their physiological function lies in the modulation of the endogenous PME activity during plant growth, development, and stress reactions (Giovane et al. 2004; Jolie et al. 2010). Our data showed that the PME activity in cold differs depending on the genotype of maize line. The secretion of specific PMEIs may modulate enzyme activity depending on their quantity or interplay with PME during plant responses to stress conditions. Searching for the genotype- or tissue-dependent mechanisms responsible for the temperature control of PME activity requires further studies.

\section{Are pectins specifically localized within the maize cell wall?}

In this work, low- and high-esterified homogalacturonans were localized using JIM5 and JIM7 antibodies, respectively, with particular attention to the cell wall around plasmodesmata in the pit fields due to suspected participation of these polysaccharides in the mechanism of plasmodesmata closure at 
Table 2 The number (mean $\pm \mathrm{SD}$ ) of gold particles conjugated to monoclonal JIM5 and JIM7 antibodies in the control (non-chilled) and chilled (for $4 \mathrm{~h}, 28 \mathrm{~h}$, and 7 days) plants of the chilling-tolerant and chilling-sensitive maize lines

\begin{tabular}{|c|c|c|c|c|c|c|c|c|c|c|c|c|c|c|c|c|}
\hline \multirow{3}{*}{ 总 } & \multicolumn{8}{|c|}{ Chilling-tolerant line } & \multicolumn{8}{|c|}{ Chilling-sensitive line } \\
\hline & \multicolumn{4}{|c|}{ JIM5 } & \multicolumn{4}{|c|}{ JIM7 } & \multicolumn{4}{|c|}{ JIM5 } & \multicolumn{4}{|c|}{ JIM7 } \\
\hline & Control & $4 \mathrm{~h}$ & $28 \mathrm{~h}$ & $7 \mathrm{~d}$ & Control & $4 \mathrm{~h}$ & $28 \mathrm{~h}$ & $7 \mathrm{~d}$ & Control & $4 \mathrm{~h}$ & $28 \mathrm{~h}$ & $7 \mathrm{~d}$ & Control & $4 \mathrm{~h}$ & $28 \mathrm{~h}$ & $7 \mathrm{~d}$ \\
\hline KMS/BS & $\begin{array}{l}101^{\mathrm{a}} \\
\pm 48\end{array}$ & $\begin{array}{l}126^{\mathrm{a}} \\
\pm 46\end{array}$ & $\begin{array}{l}127^{\mathrm{a}} \\
\pm 31\end{array}$ & $\begin{array}{l}101^{\mathrm{a}} \\
\pm 36\end{array}$ & $\begin{array}{l}321^{\mathrm{a}} \\
\pm 82\end{array}$ & $\begin{array}{l}331^{\mathrm{a}} \\
\pm 52\end{array}$ & $\begin{array}{l}303^{\mathrm{a}} \\
\pm 50\end{array}$ & $\begin{array}{l}268^{\mathrm{a}} \\
\pm 51\end{array}$ & $\begin{array}{l}131^{\mathrm{a}} \\
\pm 62\end{array}$ & $\begin{array}{c}88^{\mathrm{b}} \\
\pm 58\end{array}$ & $\begin{array}{l}80^{\mathrm{b}} \\
\pm 52\end{array}$ & $\begin{array}{l}65^{\mathrm{b}} \\
\pm 42\end{array}$ & $\begin{array}{l}446^{\mathrm{a}} \\
\pm 83\end{array}$ & $\begin{array}{l}298^{b} \\
\pm 83\end{array}$ & $\begin{array}{l}241^{b} \\
\pm 72\end{array}$ & $\begin{array}{l}214^{b} \\
\pm 59\end{array}$ \\
\hline $\mathbf{B S} / \mathbf{V P}$ & $\begin{array}{l}172^{\mathrm{a}} \\
\pm 55\end{array}$ & $\begin{array}{l}193^{\mathrm{a}} \\
\pm 62\end{array}$ & $\begin{array}{l}202^{\mathrm{a}} \\
\pm 44\end{array}$ & $\begin{array}{l}211^{\mathrm{a}} \\
\pm 62\end{array}$ & $\begin{array}{l}216^{\mathrm{a}} \\
\pm 54\end{array}$ & $\begin{array}{l}201^{\mathrm{a}} \\
\pm 83\end{array}$ & $\begin{array}{l}175^{\mathrm{a}} \\
\pm 49\end{array}$ & $\begin{array}{l}222^{\mathrm{a}} \\
\pm 69\end{array}$ & $\begin{array}{l}185^{\mathrm{a}} \\
\pm 68\end{array}$ & $\begin{array}{l}151^{\mathrm{a}} \\
\pm 66\end{array}$ & $\begin{array}{l}136^{\mathrm{a}} \\
\pm 69\end{array}$ & $\begin{array}{l}132^{\mathrm{a}} \\
\pm 57\end{array}$ & $\begin{array}{l}326^{\mathrm{a}} \\
\pm 54\end{array}$ & $\begin{array}{l}291^{\mathrm{a}} \\
\pm 83\end{array}$ & $\begin{array}{l}156^{\mathrm{b}} \\
\pm 49\end{array}$ & $\begin{array}{l}185^{b} \\
\pm 69\end{array}$ \\
\hline $\mathrm{VP} / \mathrm{CC}$ & $\begin{array}{l}255^{\mathrm{a}} \\
\pm 77\end{array}$ & $\begin{array}{l}312^{\mathrm{a}} \\
\pm 88\end{array}$ & $\begin{array}{l}251^{\mathrm{a}} \\
\pm 78\end{array}$ & $\begin{array}{l}292^{\mathrm{a}} \\
\pm 68\end{array}$ & $\begin{array}{l}305^{\mathrm{a}} \\
\pm 80\end{array}$ & $\begin{array}{l}291^{\mathrm{a}} \\
\pm 66\end{array}$ & $\begin{array}{l}315^{\mathrm{a}} \\
\pm 94\end{array}$ & $\begin{array}{l}226^{b} \\
\pm 61\end{array}$ & $\begin{array}{l}257^{a} \\
\pm 83\end{array}$ & $\begin{array}{l}256^{\mathrm{a}} \\
\pm 71\end{array}$ & $\begin{array}{l}249^{\mathrm{a}} \\
\pm 81\end{array}$ & $\begin{array}{l}232^{\mathrm{a}} \\
\pm 49\end{array}$ & $\begin{array}{l}530^{\mathrm{a}} \\
\pm 97\end{array}$ & $\begin{array}{l}450^{\mathrm{b}} \\
\pm 80\end{array}$ & $\begin{array}{l}112^{\mathrm{c}} \\
\pm 37\end{array}$ & $\begin{array}{l}127^{\mathrm{c}} \\
\pm 60\end{array}$ \\
\hline $\mathrm{VP} / \mathrm{SE}$ & $\begin{array}{l}217^{\mathrm{a}} \\
\pm 78\end{array}$ & $\begin{array}{l}264^{\mathrm{a}} \\
\pm 83\end{array}$ & $\begin{array}{l}243^{\mathrm{a}} \\
\pm 58\end{array}$ & $\begin{array}{l}413^{b} \\
\pm 76\end{array}$ & $\begin{array}{l}461^{\mathrm{a}} \\
\pm 109\end{array}$ & $\begin{array}{l}328^{\mathrm{b}} \\
\pm 83\end{array}$ & $\begin{array}{l}201^{\mathrm{c}} \\
\pm 97\end{array}$ & $\begin{array}{l}232^{\mathrm{c}} \\
\pm 68\end{array}$ & $\begin{array}{l}243^{\mathrm{a}} \\
\pm 71\end{array}$ & $\begin{array}{l}253^{\mathrm{a}} \\
\pm 69\end{array}$ & $\begin{array}{l}263^{\mathrm{a}} \\
\pm 87\end{array}$ & $\begin{array}{l}209^{\mathrm{a}} \\
\pm 55\end{array}$ & $\begin{array}{l}323^{\mathrm{a}} \\
\pm 57\end{array}$ & $\begin{array}{r}341^{\mathrm{a}} \\
\pm 137\end{array}$ & $\begin{array}{l}293^{\mathrm{a}} \\
\pm 60\end{array}$ & $\begin{array}{l}284^{\mathrm{a}} \\
\pm 62\end{array}$ \\
\hline VP/SET & $\begin{array}{c}501^{\mathrm{a}} \\
\pm 114\end{array}$ & $\begin{array}{l}529^{\mathrm{a}} \\
\pm 107\end{array}$ & $\begin{array}{l}478^{\mathrm{a}} \\
\pm 101\end{array}$ & $\begin{array}{c}569^{\mathrm{a}} \\
\pm 102\end{array}$ & $\begin{array}{c}283^{\mathrm{a}} \\
\pm 110 \\
\end{array}$ & $\begin{array}{l}245^{\text {a }} \\
\pm 76\end{array}$ & $\begin{array}{l}302^{\mathrm{a}} \\
\pm 61\end{array}$ & $\begin{array}{l}329^{\mathrm{a}} \\
\pm 78\end{array}$ & $\begin{array}{l}397^{\mathrm{a}} \\
\pm 86\end{array}$ & $\begin{array}{l}326^{\mathrm{b}} \\
\pm 87\end{array}$ & $\begin{array}{l}253^{\mathrm{c}} \\
\pm 77\end{array}$ & $\begin{array}{l}291^{\mathrm{b}} \\
\pm 74\end{array}$ & $\begin{array}{l}550^{\mathrm{a}} \\
\pm 88\end{array}$ & $\begin{array}{l}443^{b} \\
\pm 93\end{array}$ & $\begin{array}{l}301^{\mathrm{c}} \\
\pm 59\end{array}$ & $\begin{array}{l}304^{\mathrm{c}} \\
\pm 83\end{array}$ \\
\hline $\mathrm{CC} / \mathrm{SE}$ & $\begin{array}{l}180^{\mathrm{a}} \\
\pm 84\end{array}$ & $\begin{array}{l}197^{\mathrm{a}} \\
\pm 95\end{array}$ & $\begin{array}{l}213^{\mathrm{a}} \\
\pm 46\end{array}$ & $\begin{array}{l}231^{\mathrm{a}} \\
\pm 63\end{array}$ & $\begin{array}{l}291^{\mathrm{a}} \\
\pm 66\end{array}$ & $\begin{array}{c}257^{\text {a }} \\
\pm 114\end{array}$ & $\begin{array}{l}203^{b} \\
\pm 67\end{array}$ & $\begin{array}{l}205^{b} \\
\pm 63\end{array}$ & $\begin{array}{c}267^{\mathrm{a}} \\
\pm 117\end{array}$ & $\begin{array}{l}87^{\mathrm{b}} \\
\pm 50\end{array}$ & $\begin{array}{c}62^{\mathrm{b}} \\
\pm 40\end{array}$ & $\begin{array}{c}62^{\mathrm{b}} \\
\pm 47\end{array}$ & $\begin{array}{l}535^{\mathrm{a}} \\
\pm 54\end{array}$ & $\begin{array}{r}493^{\mathrm{a}} \\
\pm 105\end{array}$ & $\begin{array}{l}138^{\mathrm{b}} \\
\pm 53\end{array}$ & $\begin{array}{l}151^{\mathrm{b}} \\
\pm 64\end{array}$ \\
\hline
\end{tabular}

Data were collected in three independent experiments. Values for each variant were estimated on the basis of at least 30 cell wall sections $\left(\operatorname{area}_{1} \mu \mathrm{m}^{2}\right)$. Value for each chilling treatment was compared with value for control, for each cell interface and maize line separately. Significant differences $(P<0.01)$ estimated by Kruskal-Wallis test with Bonferroni correction are indicated by different superscript letters and shading

$K M S$ Kranz mesophyll; $B S$ bundle sheath; $V P$ vascular parenchyma; $C C$ companion cell; $S E$ thin-walled sieve tube; $S E T$ thick-walled sieve tube

cold as demonstrated earlier (Bilska and Sowiński 2010). However, no relationship between the presence of plasmodesmata and the occurrence of both types of epitopes (detected by JIM5 and JIM7) in maize leaves was found (e.g., Fig. 4f, Fig. 5f). Low-esterified pectins were previously found at the pit fields in the cell walls of tomato (Orfila and Knox 2000) and apple pericarp (Roy et al. 1997). Knox and Benitez-
Alfonso (2014) supposed that the composition of cell walls surrounding plasmodesmata significantly differs from other cell wall regions. In this work, for leaves of maize, monocotyledonous plant, the labeling was restricted to areas around plasmodesmata but not in close contact with them. It may give evidence that grass cell wall differs in the local structure and composition in comparison with the cell wall of other plants.

Table 3 Incipient plasmolysis in leaf cells in two maize inbred lines: chilling-tolerant and chilling-sensitive.

\begin{tabular}{|l|c|c|c|c|c|c|}
\hline \multirow{2}{*}{ Cell type } & \multicolumn{3}{|c|}{ Chilling-tolerant line } & \multicolumn{3}{c|}{ Chilling-sensitive line } \\
\cline { 2 - 7 } & control & $\mathbf{1 ~ h}$ & $\mathbf{4} \mathbf{h}$ & control & $\mathbf{1 ~ h}$ & $\mathbf{4 ~ h}$ \\
\hline $\begin{array}{l}\text { Kranz } \\
\text { mesophyll }\end{array}$ & 300 & 400 & 400 & 400 & 300 & 500 \\
\hline $\begin{array}{l}\text { Bundle } \\
\text { sheath }\end{array}$ & 400 & 400 & 400 & 400 & 300 & 600 \\
\hline $\begin{array}{l}\text { Vascular } \\
\text { parenchyma }\end{array}$ & 500 & 400 & 400 & 400 & 300 & 300 \\
\hline $\begin{array}{l}\text { Companion } \\
\text { cells }\end{array}$ & 500 & 500 & 400 & 300 & 300 & 200 \\
\hline $\begin{array}{l}\text { Thin-walled } \\
\text { sieve tubes }\end{array}$ & 800 & 800 & 800 & 200 & 200 & 300 \\
\hline
\end{tabular}

Values represent the concentration of sorbitol solution (in $\mathrm{mM}$ ), in which the incipient plasmolysis was observed. For improved readability different values were marked by shading. Data were collected in three independent experiments. Each variant was estimated on the basis of at least 10 vascular bundles 
Fig. 6 Examples of incipient plasmolysis in cells of control (non-chilled) (a-f) and chilled leaves for $4 \mathrm{~h}(\mathbf{g}, \mathbf{h})$ of chillingtolerant $(C T)$ and chilling-

sensitive $(C S)$ maize line incubated in different sorbitol concentration (values in rectangles). Note that protoplast is separating from the cell wall (arrowheads). KMS Kranz mesophyll; $B S$ bundle sheath; $V P$ vascular parenchyma; $C C$ companion cell; $S E$ thinwalled sieve tube; $C h$ chloroplast, $M$ mitochondria; $C W$ cell wall; Scale bar, $1 \mu \mathrm{m}$

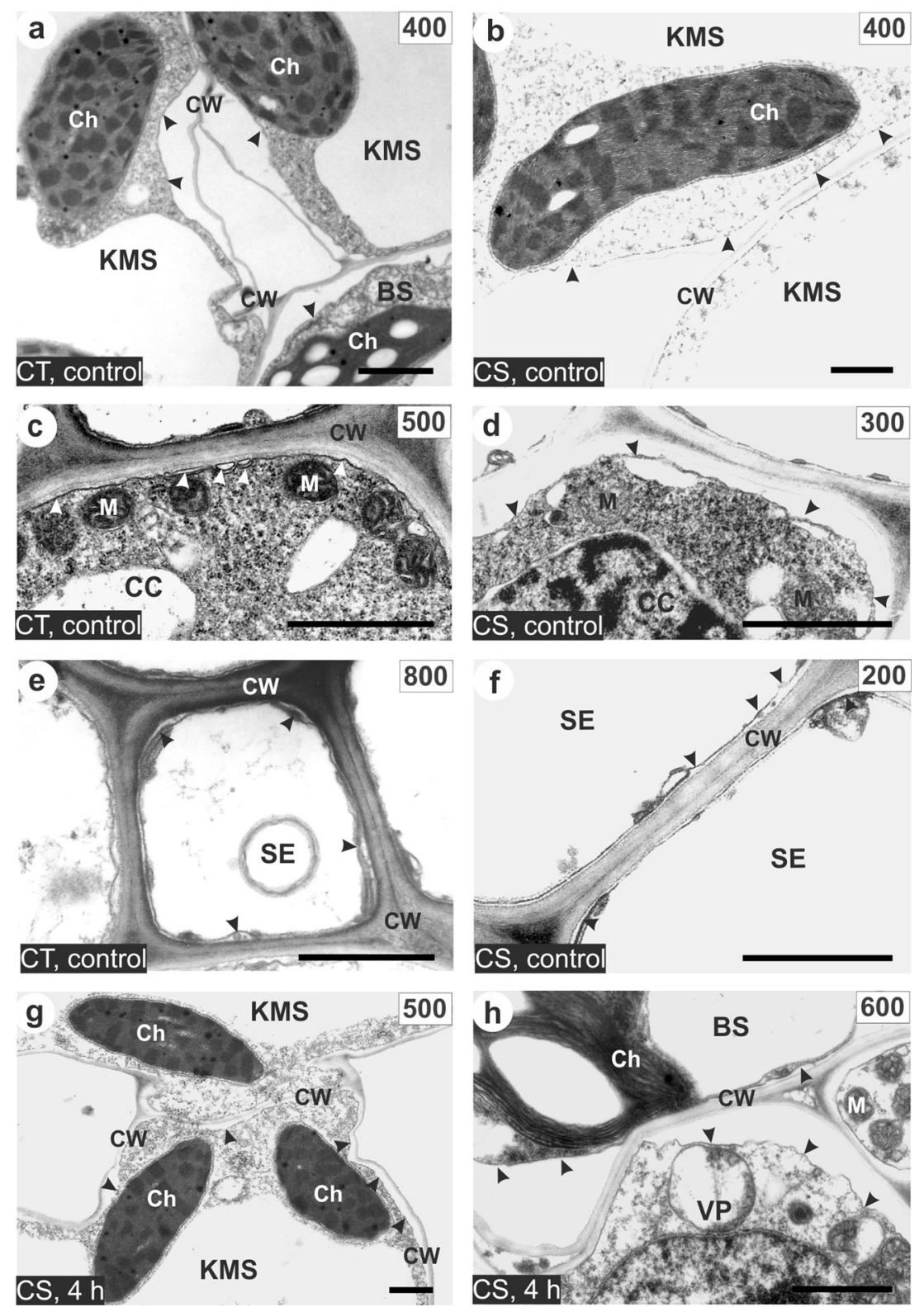

\section{May modifications of the cell wall properties be associated with cell osmoticum changes?}

The studied lines strongly differed in respect to the osmotic pressure of leaf cell, both in control and chilling-treated plants (Table 3). In the CT line, the CC/SE complex plasmolysed at higher concentration of sorbitol by about $300 \mathrm{mM}$ than the KMS, BS, and VP cells (Table 3; Fig. 6a, c, e). This demonstrates a strong solute gradient between these cells and the rest of the leaf cells, caused, as previously noted (Bilska and Sowiński 2010), by an efficient apoplasmic phloem loading of sucrose in CT line. Similar difference in osmotic potential of leaf cells was found by Evert et al. (1978). In contrast to CT line, in control plants of CS line, the CC/SE complex plasmolysed at lower osmoticum concentrations than required to plasmolyse the KMS, BS and VP cells (Table 3; Fig. 6b, d, f). In specific regions of the maize leaf, gradient of the osmotic potential of photosynthetic active cells may be related to the type of phloem loading and ultrastructural differences. Thus, in CS maize line, sucrose transport from mesophyll to vein does not need to undergo against concentration gradient, similarly as in some species showing no apoplasmic phloem loading (Turgeon and Medville 1998). The possibility that active phloem loading (defined as photosynthate transport to the $\mathrm{CC}$ / SE complex against the concentration gradient) might not be necessary in some plants was discussed by Turgeon (2006). 


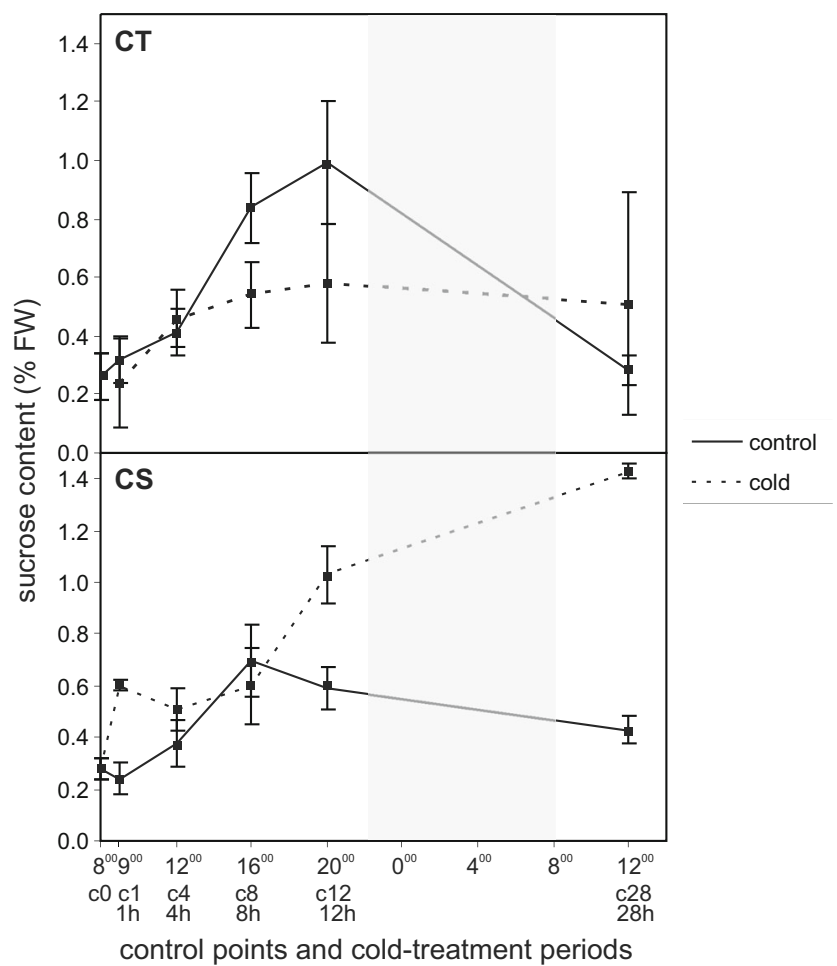

Fig. 7 Sucrose content expressed as a percentage of fresh weight (FW) in leaves of two maize lines: chilling-tolerant $(C T)$ and chilling-sensitive $(C S)$ treated with low temperature for several time periods: 1, 4, 8, 12, and $28 \mathrm{~h}$ with corresponding time points for control (non-chilled) plants: $\mathrm{c} 0, \mathrm{c} 1, \mathrm{c} 4, \mathrm{c} 8, \mathrm{c} 12$, and $\mathrm{c} 28$. The shaded area-period with the light off (night). Bars represent the mean \pm SD values

The observation that osmotic pressure of the CC/SE complex in leaves of CS line seedlings is lower than in adjacent cells is in line with our earlier finding, where the CC/SE complex in leaves of dent type maize lines might not be fully isolated symplasmically from the rest of the leaf (Sowiński et al. 2001, 2003). This might reflect ultrastructural differences in juvenile leaf development between $Z$. mays indurata and $Z$. mays indentata at this physiological stage.

Changes in the osmotic potential of plant cells may occur due to the accumulation of photosynthesis products, especially sucrose with strong osmotic properties (Wolfe 1991). In chilled leaves of CS line, sucrose is accumulated just after $1 \mathrm{~h}$ of chilling treatment and remains at high level during the dark (Fig. 7). Hence, it can be assumed that sucrose which was accumulated in KMS, BS, and VP cells could reduce their osmotic potential. The reason for the inhibition of sucrose transport to the CC/SE complex may be rapid changes of plasmodesmata ultrastructure and thus their reduced permeability under cold conditions (Bilska and Sowiński 2010). The most significant differences between tested maize lines were changes in the osmotic potential (Table 3) and the accumulation of sucrose (Fig. 7) after $4 \mathrm{~h}$ of chilling treatment. It is known that the osmotic stress induced by $\mathrm{NaCl}$ caused changes in the chemical composition of primary cell wall of tobacco (Iraki et al. 1989a, b). These changes, including decrease of soluble pectin content, were accompanied with the inhibition of cell growth. On the other hand, the relationship between the osmotic adjustment and cell expansion may be different in various organs of plants (Westgate and Boyer 1985). For instance, in water-limited conditions the growth of maize silk is more limited than roots (Westgate and Boyer 1985). The maintenance of turgor in cells under water deficit is crucial to provide the appropriate properties of the cell wall, i.e., elasticity. In addition, $\mathrm{C}_{4}$ grasses have a better ability of adjusting the osmotic potential than $\mathrm{C}_{3}$ grasses, which help them to adapt to water-limited conditions (Barker et al. 1993).

In this work, cell-specific changes of osmotic potential can affect the composition of the cell wall by reducing the global amount of pectins in chilled plants of CS line rather than by the modification of their methylesterification degree. It is possible, that this reduction, at least partially, is related to the activity of another enzyme, polygalacturonase, where its control is dependent on a variety of stress factors, including cold (D'Ovidio et al. 2004; Almeida and Huber 2010; Liu et al. 2014). Additionally, it is possible that by the interaction with the wall-associated protein kinases (WAKs), pectins take part in the signal transduction between cell wall and plasma membrane, and in the control of the distribution of cell wall components (Haswell and Verslues 2015). Then, a relatively rapid change in the osmotic potential, which was observed mainly in the CS line, could be "the starting point" for profound rearrangement of cell wall pectins in this maize line.

\section{Conclusions}

This work shows that low temperature affects the content of cell wall pectins in maize leaves. Local changes in the osmotic potential in leaves of chilled plants of chillingsensitive maize line, as the result of the rapid accumulation of sucrose (observed after just $1 \mathrm{~h}$ of chilling treatment, probably due to the blockage of its transport via cold-modified plasmodesmata) may lead to significant changes in the pectin organization. These changes might be found as indirect effect of cold stress or mechanism of plant adjustment to adverse environmental condition. Our results indicate that this problem is very important for the breeding of chilling-sensitive plants and it is worth pursuing.

Acknowledgments The authors wish to thank anonymous Reviewers for suggestions that have greatly improved the clarity of the paper. We wish to thank Dr. J. Leipner, ETH, Zürich for providing the seeds. TEM 
observation was performed in the Laboratory of Electron Microscopy, Nencki Institute of Experimental Biology, PAS, Warsaw, Poland. This work was financially supported by grant No 5496/B/P01/2010/39 from the National Science Centre, Poland.

\section{Compliance with ethical standards}

Conflict of interest The authors declare that they have no conflict of interest.

Open Access This article is distributed under the terms of the Creative Commons Attribution 4.0 International License (http:// creativecommons.org/licenses/by/4.0/), which permits unrestricted use, distribution, and reproduction in any medium, provided you give appropriate credit to the original author(s) and the source, provide a link to the Creative Commons license, and indicate if changes were made.

\section{References}

Almeida DPF, Huber DJ (2010) Differing patterns of pectin disassembly and pericarp softening in ripening and chill-injured tomato fruit with downregulated polygalacturonase activity. J Food Biochem 34:368381

Balestrieri C, Castaldo D, Giovane A, Quagliuolo L, Servillo L (1990) A glycoprotein inhibitor of pectin methylesterase in kiwi fruit (Actinidia chinensis). Eur J Biochem 193:183-187

Barker DJ, Sullivan CY, Moser LE (1993) Water deficit effects on osmotic potential, cell wall elasticity, and proline in five forage grasses. Agron J 85:270-275

Bilska A, Sowiński P (2010) Closure of plasmodesmata in maize (Zea mays) at low temperature: a new mechanism for inhibition of photosynthesis. Ann Bot 106:675-686

Bradford MM (1976) A rapid and sensitive method for the quantitation of microgram quantities of protein utilizing the principle of protein-dye binding. Anal Biochem 72:248-254

Catoire L, Pierron M, Morvan C, du Penhoat CH, Goldberg R (1998) Investigation of the action patterns of pectinmethylesterase isoforms through kinetic analyses and NMR spectroscopy. J Biol Chem 273: $33150-33156$

Clausen MH, Willats WGT, Knox JP (2003) Synthetic methyl hexagalacturonate hapten inhibitors of anti-homogalacturonan monoclonal antibodies LM7, JIM5 and JIM7. Carbohydr Res 338: $1797-1800$

Domon J-M, Baldwin L, Acket S, Caudeville E, Arnoult S, Zub H, Gillet F, Lejeune-Hénaut I, Brancourt-Hulmel M, Pelloux J, Rayon C (2013) Cell wall compositional modifications of Miscanthus ecotypes in response to cold acclimation. Phytochem 85:51-61

Douchiche O, Driouich A, Morvan C (2010) Spatial regulation of cellwall structure in response to heavy metal stress: cadmium-induced alteration of the methyl-esterification pattern of homogalacturonans. Ann Bot 105:481-491

D’Ovidio R, Mattei B, Roberti S, Bellincampi D (2004) Polygalacturonases, polygalacturonase-inhibiting proteins and pectic oligomers in plant-pathogen interactions. Biochimica et Biophysica Acta (BBA) - Proteins and Proteomics 1696:237-244

Eticha D, Stass A, Horst WJ (2005) Cell-wall pectin and its degree of methylation in the maize root-apex: significance for genotypic differences in aluminium resistance. Plant Cell Environ 28:1410-1420

Evert RF, Eschrich W, Heyser W (1978) Leaf structure in relation to solute transport and phloem loading in Zea mays L. Planta 138: 279-294
Evert RF, Russin WA, Bosabalidis M (1996) Anatomical and ultrastructural changes associated with sink-to-source transition in developing maize leaves. Int J Plant Sci 157:247-261

Fan L, Linker R, Gepstein S, Tanimoto E, Yamamoto R, Neumann PM (2006) Progressive inhibition by water deficit of cell wall extensibility and growth along the elongation zone of maize roots is related to increased lignin metabolism and progressive stelar accumulation of wall phenolics. Plant Physiol 140:603-612

Fernandes JC, García-Angulo P, Goulao LF, Acebes JL, Amâncio S (2013) Mineral stress affects the cell wall composition of grapevine (Vitis vinifera L.) callus. Plant Sci 205-206:111-120

Giovane A, Servillo L, Balestrieri C, Raiola A, D’Avino R, Tamburrini M, Ciardiello MA, Camardella L (2004) Pectin methylesterase inhibitor. Biochim Biophys Acta 1696:245-252

Haswell ES, Verslues PE (2015) The ongoing search for the molecular basis of plant osmosensing. J Gen Physiol 145:389-394

Hattersley PW (1984) Characterization of C4 type leaf anatomy in grasses (Poaceae). Mesophyll: bundle sheath area ratios. Ann Bot 53:163180

Hongo S, Sato K, Yokoyama R, Nishitani K (2012) Demethylesterification of the primary wall by PECTIN METHYLESTERASE35 provides mechanical support to the Arabidopsis stem. Plant Cell 24:2624-2634

Hossain AKMZ, Koyama H, Hara T (2006) Growth and cell wall properties of two wheat cultivars differing in their sensitivity to aluminum stress. J Plant Physiol 163:39-47

Iraki NM, Bressan RA, Carpita NC (1989a) Extracellular polysaccharides and proteins of tobacco cell cultures and changes in composition associated with growth-limiting adaptation to water and saline stress. Plant Physiol 91:54-61

Iraki NM, Bressan RA, Hasegawa PM, Carpita NC (1989b) Alteration of the physical and chemical structure of the primary cell wall of growth-limited plant cells adapted to osmotic stress. Plant Physiol 91:39-47

Jiang Y, Yao Y, Wang Y (2012) Physiological response, cell wall components, and gene expression of switchgrass under short-term drought stress and recovery. Crop Sci 52:2718-2727

Jolie RP, Duvetter T, Van Loey AM, Hendrickx ME (2010) Pectin methylesterase and its proteinaceous inhibitor: a review. Carbohydr Res 345:2583-2595

Knox JP, Benitez-Alfonso Y (2014) Roles and regulation of plant cell walls surrounding plasmodesmata. Curr Opin Cell Biol 22:93-100

Knox JP, Linstead PJ, King J, Cooper C, Roberts K (1990) Pectin esterification is spatially regulated both within cell walls and between developing tissues of root apices. Planta 181:512-521

Knudsen KEB, Li BW (1991) Determination of oligosaccharides in protein-rich feedstuffs by gas-liquid chromatography and highperformance liquid chromatography. J Agric Food Chem 39:689694

Kubacka-Zębalska M, Kacperska A (1999) Low temperature-induced modifications of cell wall content and polysaccharide composition in leaves of winter oilseed rape (Brassica napus L. var. oleifera L.). Plant Sci 148:59-67

Lima RB, dos Santos TB, Vieira LGE, Ferrarese MLL, Ferrarese-Filho O, Donatti L, Boeger MRT, Petkowicz CLO (2013) Heat stress causes alterations in the cell-wall polymers and anatomy of coffee leaves (Coffea arabica L.). Carbohydr Polym 93:135-143

Lima RB, dos Santos TB, Vieira LGE, Ferrarese MLL, Ferrarese-Filho O, Donatti L, Boeger MRT, Petkowicz CLO (2014) Salt stress alters the cell wall polysaccharides and anatomy of coffee (Coffea arabica L.) leaf cells. Carbohydr Polym 112:686-694

Liu Q, Talbot M, Llewellyn DJ (2013) Pectin methylesterase and pectin remodelling differ in the fibre walls of two Gossypium species with very different fibre properties. PLoS One 8, e65131

Liu H, Ma Y, Chen N, Guo S, Liu H, Guo X, Chong K, Xu Y (2014) Overexpression of stress-inducible OsBURP16, the $\beta$ subunit of 
polygalacturonase 1 , decreases pectin content and cell adhesion and increases abiotic stress sensitivity in rice. Plant Cell Environ 37: $1144-1158$

Mohnen D (2008) Pectin structure and biosynthesis. Curr Opin Plant Biol 11:266-277

Moore JP, Nguema-Ona E, Chevalier L, Lindsey GG, Brandt WF, Lerouge P, Farrant JM, Driouich A (2006) Response of the leaf cell wall to desiccation in the resurrection plant Myrothamnus flabellifolius. Plant Physiol 141:651-662

Morvan O, Quentin M, Jauneau A, Mareck A, Morvan C (1998) Immunogold localization of pectin methylesterases in the cortical tissues of flax hypocotyl. Protoplasma 202:175-184

Muszyńska A, Jarocka K, Kurczynska E (2014) Plasma membrane and cell wall properties of an aspen hybrid (Populus tremula $\times$ tremuloides) parenchyma cells under the influence of salt stress. Acta Physiol Plant 36:1155-1165

O'Neill MA, York WS (2003) The composition and structure of plant primary cell walls. In: Rose JKC (ed) The plant cell wall. WileyBlackwell, Oxford, pp 1-54

Orfila C, Knox JP (2000) Spatial regulation of pectic polysaccharides in relation to pit fields in cell walls of tomato fruit pericarp. Plant Physiol 122:775-782

Park YB, Cosgrove DJ (2015) Xyloglucan and its interactions with other components of the growing cell wall. Plant Cell Physiol 56:180-194

Parre E, Geitmann A (2005) Pectin and the role of the physical properties of the cell wall in pollen tube growth of Solanum chacoense. Planta 220:582-592

Ridley BL, O’Neill MA, Mohnen D (2001) Pectins: structure, biosynthesis, and oligogalacturonide-related signaling. Phytochemistry 57: 929-967

Roy S, Watada AE, Wergin WP (1997) Characterization of the cell wall microdomain surrounding plasmodesmata in apple fruit. Plant Physiol 114:539-547

Schols HA, Bakx EJ, Schipper D, Voragen AGJ (1995) A xylogalacturonan subunit present in the modified hairy regions of apple pectin. Carbohydr Res 279:265-279

Siedlecka A, Wiklund S, Peronne MA, Micheli F, Lesniewska J, Sethson I, Edlund U, Richard L, Sundberg B, Mellerowicz EJ (2008) Pectin methyl esterase inhibits intrusive and symplastic cell growth in developing wood cells of Populus. Plant Physiol 146:554-565

Sobkowiak A, Jończyk M, Jarochowska E, Biecek P, TrzcinskaDanielewicz J, Leipner J, Fronk J, Sowiński P (2014) Genome- wide transcriptomic analysis of response to low temperature reveals candidate genes determining divergent cold-sensitivity of maize inbred lines. Plant Mol Biol 85:317-331

Solecka D, Żebrowski J, Kacperska A (2008) Are pectins involved in cold acclimation and de-acclimation of winter oil-seed rape plants? Ann Bot 101:521-530

Sowiński P (1995) Transport of assimilates from leaves to roots in coldtreated maize seedlings. Kinetics and assimilate distribution. Acta Physiol Plant 17:341-348

Sowiński P, Rudzińska-Langwald A, Dalbiak A, Sowińska A (2001) Assimilate export from leaves of chilling-treated seedlings of maize. The path to vein. Plant Physiol Biochem 39:881-889

Sowiński P, Rudzińska-Langwald A, Kobus P (2003) Changes in plasmodesmata frequency in vascular bundles of maize seedling leaf induced by growth at sub-optimal temperatures in relation to photosynthesis and assimilate export. Environ Exp Bot 50:183-196

Trzcinska-Danielewicz J, Bilska A, Fronk J, Zielenkiewicz P, Jarochowska E, Roszczyk M, Jończyk M, Axentowicz E, Skoneczny M, Sowiński P (2009) Global analysis of gene expression in maize leaves treated with low temperature: I. Moderate chilling $\left(14^{\circ} \mathrm{C}\right)$. Plant Sci 177:648-658

Turgeon R (2006) Phloem loading: how leaves gain their independence. Bioscience 56:15-24

Turgeon R, Medville R (1998) The absence of phloem loading in willow leaves. Proc Natl Acad Sci U S A 95:12055-12060

Westgate ME, Boyer JS (1985) Osmotic adjustment and the inhibition of leaf, root, stem and silk growth at low water potentials in maize. Planta 164:540-549

Willats WT, McCartney L, Mackie W, Knox JP (2001) Pectin: cell biology and prospects for functional analysis. Plant Mol Biol 47:9-27

Wolfe DW (1991) Low temperature effects on early vegetative growth, leaf gas exchange and water potential of chilling-sensitive and chilling-tolerant crop species. Ann Bot 67:205-212

Wu Y, Sharp RE, Durachko DM, Cosgrove DJ (1996) Growth maintenance of the maize primary root at low water potentials involves increases in cell-wall extension properties, expansin activity, and wall susceptibility to expansins. Plant Physiol 111:765-772

Yang ZB, Eticha D, Rao IM, Horst WJ (2010) Alteration of cell-wall porosity is involved in osmotic stress-induced enhancement of aluminium resistance in common bean (Phaseolus vulgaris L.). J Exp Bot 61:3245-3258 